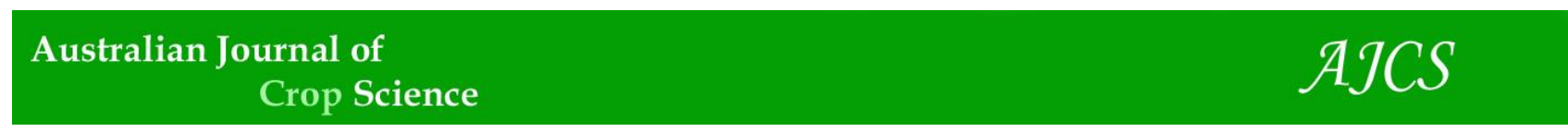

AJCS 11(09):1210-1215 (2017)

ISSN:1835-2707

doi: 10.21475/ajcs.17.11.09.pne561

\title{
Development and yield of maize in response to inoculation of associative diazotrophic bacteria and nitrogen doses
}

\author{
Julio Cezar Fornazier Moreira ${ }^{1}$, Salomão Lima Guimarães ${ }^{1 *}$, Erineudo Lima Canuto ${ }^{2}$, Edna Maria \\ Bonfim-Silva ${ }^{1}$
}

${ }^{1}$ Federal University of Mato Grosso, Department of Agricultural and Environmental Engineering, Institute of Agricultural Sciences and Technology, Road Rondonópolis/Guiratinga, Km 06, 78735-901, Rondonópolis, MT, Brazil

${ }^{2}$ Federal University of Mato Grosso, Department of Agricultural and Environmental Engineering, Institute of Agricultural Sciences and Technology, Road Rondonópolis/Guiratinga, Km 06, 78735-901, Rondonópolis, MT, Brazil

${ }^{3}$ Federal Institute of Education, Science and Technology Mato Grosso, 78106-000, Santo Antônio do Leverger, MT, Brasil

*Corresponding/Senior author: slguimaraes@ufmt.br

\begin{abstract}
The use of diazotrophic bacteria features an important alternative to nitrogen $(\mathrm{N})$ supply to crops. However, the efficiency of biological nitrogen fixation (BNF) depends on the capacity of bacterial-plant interaction. One strategy to improve this interaction is to select bacterial strains adapted to local edaphoclimatic conditions. Thus, we hypothesized that diazotrophic bacteria isolated under local edaphoclimatic conditions have a better efficiency of interaction with the plant, resulting in a greater $\mathrm{N}$ supply capacity for the Zea mays crop. This study evaluated the effects of inoculation of diazotrophic bacteria and $\mathrm{N}$ doses on the development, yield and nutrition of maize grown in Campo Verde (Mato Grosso, Brazil) in the 2013/2014 crop season. The experiment was conducted under a randomized block design in bifactorial scheme $4 \times 3$. The treatments consisted of a commercial inoculant (strains Ab-V5 and Ab-V6 of Azospirillum brasilense), two isolates of associative diazotrophic bacteria (MTAz8 and MTh2, similar to Azospirillum sp. and Bacillus sp., respectively) and absence of inoculation (control), combined with three $\mathrm{N}$ doses $\left(0,55 \mathrm{and} 110 \mathrm{~kg} \cdot \mathrm{ha}^{-1}\right)$ with four replicates. Plant height, spike insertion, stem diameter, chlorophyll index, $\mathrm{N}$ concentration in leaves and grains, grain yield and aboveground dry matter were evaluated. There was significant interaction of inoculation and $\mathrm{N}$ doses in aboveground dry matter. The other variables, except for stem diameter, were influenced by only one factor, inoculation or $\mathrm{N}$ doses. Our results show that inoculation of isolates MTAz8 and MTh2 promotes a substantial increase in the production of aboveground dry matter in relation to the commercial inoculant, confirming our hypothesis. In addition, our results suggest that inoculation promotes increases in grain yield, even without application of $\mathrm{N}$ fertilizer.
\end{abstract}

Key words: Azospirillum brasilense, growth, aboveground dry matter, nitrogen biological fixation, Zea mays L.

Abbreviations: Ab_Azospirillum brasilense; BNF_biological nitrogen fixation; CI_chlorophyll index; DAS_days after sowing; GNC_grain nitrogen concentration; LNC_leaf nitrogen concentration; N_nitrogen; PH_plant height; DM_aboveground dry matter; HIS_spike insertion; SD_stem diameter; Y_Yield.

\section{Introduction}

Maize (Zea Mays L.) is a species of the Poaceae family cultivated worldwide. In Brazil, maize production in the 2013-2014 crop accounted for $40 \%$ of the total of 207.6 million tons of grains produced. Mato Grosso State is the major maize producer in Brazil with a planted area of $3,200,000$ ha and total production $17,720,000$ tons for the 2013-2014 crop (CONAB, 2014). This makes maize an essential food, as it is used in human and animal nutrition also serving as a raw material for various industrial processes. Nitrogen is one of the nutrients most demanded by plants, because it composes most molecules of organic compounds, such as amino acids and proteins. $\mathrm{N}$ is also part of various vital processes to the plant, such as protein synthesis, ionic absorption, photosynthesis, respiration, multiplication and cellular differentiation (Malavolta, 2006).
This makes $\mathrm{N}$ essential for various parameters related to plant growth, which affect directly or indirectly grain yield of the culture (Gomes et al., 2007, Duete et al., 2008, Okumura et al., 2011). The maize culture absorbs and exports, in the form of grain and biomass, large amounts of $\mathrm{N}$ from the soil, which require $\mathrm{N}$ fertilization in most producing regions. Conversely, $\mathrm{N}$ increases crop production costs, because the industrial production of $\mathrm{N}$ demands a high consumption of energy usually from fossil fuels (Cantarella and Duarte, 2004). In view of the growing demand for $\mathrm{N}$ fertilizers, especially for grasses, and the concern with the losses and environment contamination (Piccini et al., 2016), mainly by volatilization, denitrification and leaching, the search for technologies that enable $\mathrm{N}$ supply to plants sustainably (biologically) becomes necessary. Therefore, inoculation with 
associative diazotrophic bacteria represents a promising alternative for the partial replacement of $\mathrm{N}$ fertilizer supplied to the maize culture (Moreira et al., 2010).

The process of BNF performed by diazotrophic bacteria breaks the triple bond between the two molecules of atmospheric N, reducing it to ammonia by means of an enzyme called nitrogenase (Reis and Teixeira, 2005). In addition to the ability to fix atmospheric $\mathrm{N}$, these microorganisms can synthesize substances that act on plant growth, such as auxins, gibberellins, and cytokinins. These substances induce a better development of the root system that results in higher uptake rates of water and nutrients, promoting more vigorous and productive plants (Santi et al., 2013). Previous studies have reported the potential for diazotrophic bacteria to supply fixed $\mathrm{N}$ to non-legume plants, including maize. With the main objective to increase efficiency in the association between the diazotrophic bacteria and the plant, we directed the studies to the identification of strains adapted to the specific soil and climatic conditions of the region. Thus, we hypothesized that isolated diazotrophs under local climatic conditions have greater potential for adaptation to the specific edaphoclimatic conditions of the region. This study aimed to evaluate the effect of inoculation with associative diazotrophic bacteria and $\mathrm{N}$ doses on growth, nutrition and yield of maize grown in Mato Grosso State during the crop period.

\section{Results and Discussion}

The interaction between the factors, inoculation of associative diazotrophic bacteria and $\mathrm{N}$ doses affected the production of aboveground dry matter. The other parameters showed no interaction, however, both factors influenced the height of spike insertion and $\mathrm{N}$ concentration in the grains. Plant height, chlorophyll index, foliar $\mathrm{N}$ concentration and grain yield were influenced by the $\mathrm{N}$ fertilizer application. The stem diameter, however, was not affected by the studied factors (Table 2).

\section{Plant morphological characteristics}

Plant height was not influenced by the inoculation of diazotrophic bacteria in the two stages assessed (Table 3). These results corroborate with other studies, where inoculation of maize seeds did not provide positive results for plant growth (Cavallet et al., 2000; Dartora et al., 2013). N fertilization provided the highest values for plants height, regardless of the dose, in the two assessments (Table 3).

The height of spike insertion was influenced, in isolation, by inoculation and $\mathrm{N}$ doses (Table 3 ). In both assessments, plants that did not receive inoculations showed greater height of spike insertion. On the other hand, the lowest height of spike insertion was found in plants inoculated with isolate MTh2. The supply of $55 \mathrm{~kg} \mathrm{ha}^{-1}$ of $\mathrm{N}$ resulted in greater height of spike insertion, although it did not differ with 110 $\mathrm{kg} \mathrm{ha}^{-1}$ of N. Similar results were obtained by Souza and Soratto (2006) who found the maximum height of spike insertion $(0.82 \mathrm{~m})$ with the application of $70 \mathrm{~kg} \mathrm{ha}^{-1}$ of $\mathrm{N}$.

Activity and survival of the soil microbial community are influenced by several factors; thus, the greater height obtained from plants that did not receive inoculation could be associated with efficiency of microorganisms that naturally occur in the soil, which were possibly favored by climatic conditions (temperature and humidity) during the experiment (Brandão, 1992), as well as by the high OM content found in the experimental area $\left(29.3 \mathrm{~g} \mathrm{dm}^{-3}\right)$, which is an important indicator of soil microbial biomass (Conceição et al., 2005).
Stem diameter was not influenced by any of the factors studied in both assessment periods (Table 3); corroborating Kappes et al. (2013) who did not obtain responses with inoculation of Azospirillum brasilense for stem diameter in maize. On the other hand, Dartora et al. (2013) observed increases of stem diameter of maize plants inoculated with a combination of strains of A. brasilense and Herbaspirillum seropedicae, in relation to the control (without inoculation).

\section{Plant nutritional characteristics}

The chlorophyll index is a parameter used to predict the nutritional level of $\mathrm{N}$ in plants, since the addition of $\mathrm{N}$ fertilizers reflects directly on the index increases (Table 3 ). The positive relationship between $\mathrm{N}$ supply and chlorophyll content is attributed to the fact that more than $50 \%$ of total $\mathrm{N}$ of leaves comprises the compounds of chloroplast and chlorophyll from the leaves (Chapman and Barreto, 1997). In this study, the inoculation with diazotrophic bacteria showed no influence on the chlorophyll index in the two assessment of maize cultivation (Table 3). Kappes et al. (2013) also found no significant differences in the assessment of chlorophyll index in maize plants inoculated with Azospirillum brasilense. Inoculation influenced negatively $\mathrm{N}$ concentration in the grains, however, there was no influence on the leaves. $\mathrm{N}$ fertilization resulted in greater concentration in both compartments (Table 3 ). The results corroborate Dotto et al. (2010) who showed that inoculation with $H$. seropedicae did not influence the increase of $\mathrm{N}$ concentration in the leaves nor in the grains of maize plants. Different results were reported by Quadros et al. (2014) who obtained significant and higher results by inoculating maize seeds with a mixture of three species of Azospirillum.

The supply of $\mathrm{N}$ fertilizer at $110 \mathrm{~kg} \mathrm{ha}^{-1}$ resulted in higher $\mathrm{N}$ concentrations in the leaves and grains. Nevertheless, foliar $\mathrm{N}$ concentration showed no significant difference between the dose $55 \mathrm{~kg} \mathrm{ha}^{-1}$ and the highest $\mathrm{N}$ dose. There were increases of 10 and $5.1 \%$ in foliar $\mathrm{N}$ concentration with 110 and $55 \mathrm{~kg}$ $\mathrm{ha}^{-1}$ of $\mathrm{N}$, respectively, in relation to the absence of $\mathrm{N}$ supply. The higher $\mathrm{N}$ dose $\left(110 \mathrm{~kg} \mathrm{ha}^{-1}\right)$ provided $11.13 \%$ increase in $\mathrm{N}$ concentration in maize grains in relation to the absence of $\mathrm{N}$ fertilizer (Table 3 ).

According to Malavolta (2006), foliar N concentration, which represents the adequate nutrition of maize crops, is between 27 to $35 \mathrm{~g} \mathrm{~kg}^{-1}$. Therefore, the data observed in the present study indicate that only the treatments without $\mathrm{N}$ fertilization showed concentrations below the range proposed as appropriate. The absence of significant responses due to inoculation may be attributed to the optimal conditions of precipitation and temperature found during the growth period of the crop. The climate data presented in Fig. 1 indicate that during this period, air temperature was suitable for crop development, given that production is favored at moderate temperatures, between 18 and $25^{\circ} \mathrm{C}$. Similarly, precipitation was appropriate and water was available for plant growth and development, $\mathrm{OM}$ mineralization and increased $\mathrm{N}$ availability (Kappes et al., 2013), which provided favorable conditions for plant growth even in conditions without $\mathrm{N}$ fertilization, which may have neutralized the inoculation effects.

\section{Plant productive characteristics}

The aboveground dry matter (DM) production was influenced by the interaction between inoculation and $\mathrm{N}$ doses. The inoculation of MTh2 associated with the supply of $55 \mathrm{~kg} \mathrm{ha}^{-1}$ of $\mathrm{N}$ provided greater DM production. However, it differed from the DM production obtained with inoculation of the same isolate associated with the supply of $110 \mathrm{~kg} \mathrm{ha}^{-1}$ of $\mathrm{N}$, 
Table 1. Soil chemical characteristics in the experimental area before the start of the experiment $(0-0.2 \mathrm{~m})$.

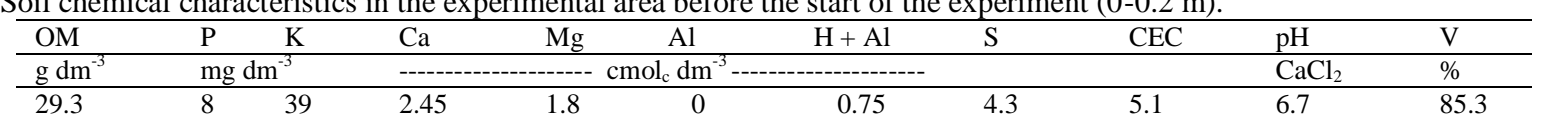

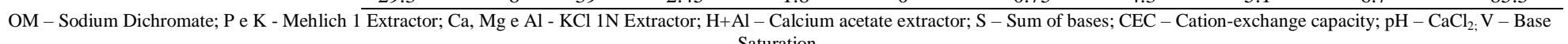

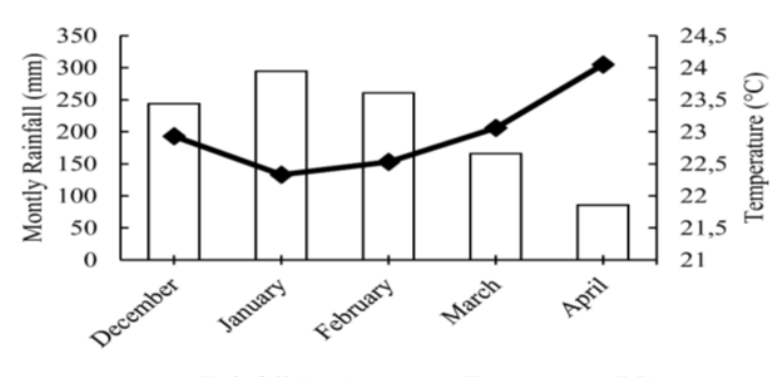

Rainfall (mm) -Temperature $\left({ }^{\circ} \mathrm{C}\right)$

Fig 1. Climate data obtained from the INMET weather station in Campo Verde, Mato Grosso State, Brazil, from December 2013 to April 2014.

Table 2. Summary of the analysis of variance for the results of plant height (PH), and spike insertion (HSI), stem diameter (SD), chlorophyll index (CI) and leaf nitrogen concentration (LNC), grain nitrogen concentration (GNC), Aboveground dry matter (DM) and Yield (Y) of maize plants influenced by inoculation of associative diazotrophic bacteria and nitrogen fertilization.

\begin{tabular}{|c|c|c|c|c|c|c|c|c|c|c|c|c|c|}
\hline \multirow{3}{*}{$\mathrm{VF}$} & \multirow{3}{*}{$\mathrm{DF}$} & \multicolumn{12}{|c|}{ Mean Square } \\
\hline & & \multicolumn{2}{|c|}{$\begin{array}{c}\mathrm{PH} \\
(\mathrm{cm})\end{array}$} & \multicolumn{2}{|c|}{$\begin{array}{l}\mathrm{HSI} \\
(\mathrm{cm})\end{array}$} & \multicolumn{2}{|c|}{$\begin{array}{c}\mathrm{SD} \\
(\mathrm{mm})\end{array}$} & \multicolumn{2}{|c|}{$\mathrm{CI}$} & \multirow{2}{*}{$\begin{array}{c}\begin{array}{c}\mathrm{LNC} \\
\left(\mathrm{g} \cdot \mathrm{kg}^{-1}\right)\end{array} \\
\mathrm{VT}\end{array}$} & \multirow[t]{2}{*}{$\begin{array}{c}\mathrm{GNC} \\
\left(\mathrm{g} \cdot \mathrm{kg}^{-1}\right)\end{array}$} & \multirow[t]{2}{*}{$\begin{array}{c}\mathrm{DM} \\
\left(\mathrm{kg} \cdot \mathrm{ha}^{-1}\right)\end{array}$} & \multirow[t]{2}{*}{$\begin{array}{c}\mathrm{Y} \\
\left(\mathrm{kg} \cdot \mathrm{ha}^{-1}\right)\end{array}$} \\
\hline & & VT & R3 & VT & R3 & VT & R3 & VT & R3 & & & & \\
\hline Inoculation (I) & 3 & $154.51^{\mathrm{ns}}$ & $83.04^{\mathrm{ns}}$ & $145.03 * *$ & $82.00^{* * *}$ & $2.82^{\mathrm{ns}}$ & $3.94^{\mathrm{ns}}$ & $2.73^{\text {ns }}$ & $12.91^{\mathrm{ns}}$ & $7.35^{\mathrm{ns}}$ & $4.75 * *$ & 212997.94 & 11625.08 \\
\hline Nitrogen doses $(\mathrm{N})$ & 2 & $1250.64 * *$ & $498.71 * *$ & $91.21 *$ & $93.03^{* *}$ & $6.84^{\mathrm{ns}}$ & $6.65^{\mathrm{ns}}$ & $79.34^{\mathrm{ns}}$ & $112.66^{* *}$ & $28.81^{\mathrm{ns}}$ & $11.26 * *$ & $2089778.41 * *$ & $3927744.18 * *$ \\
\hline Ix N & 6 & $52.40^{\text {ns }}$ & $25.09^{\text {ns }}$ & $28.68^{\text {ns }}$ & $11.65^{\mathrm{ns}}$ & $1.31^{\mathrm{ns}}$ & $4.55^{\mathrm{ns}}$ & $9.90^{\mathrm{ns}}$ & $5.49^{\mathrm{ns}}$ & $4.81^{\mathrm{ns}}$ & 0.85 & $1305663.02 *$ & 1322898.34 \\
\hline Blocks & 3 & 492.09 & 465.05 & 200.59 & 146.33 & 4.91 & 10.12 & 3.29 & 15.71 & 11.42 & 0.51 & 1459609.57 & 1179829.79 \\
\hline Residual & 33 & 81.58 & 48.43 & 25.68 & 23.55 & 3.25 & 3.58 & 7.03 & 10.70 & 5.37 & 1.75 & 677641.99 & 1107696.46 \\
\hline C.V. (\%) & & 5.11 & 3.84 & 6.11 & 5.33 & 7.71 & 9.27 & 4.97 & 6.04 & 8.22 & 9.24 & 16.66 & 14.34 \\
\hline
\end{tabular}

** Significant to $\mathrm{p}<0.01 ;$ *significant to $\mathrm{p}<0.05$; ${ }^{\mathrm{n}}$ non-significant at $\mathrm{p}<0.05$ by $\mathrm{F}$ test; $\mathrm{VF}-$ Variation factor; $\mathrm{DF}$ - Degree free

Table 3. Plant height (PH), and spike insertion (HSI), stem diameter (SD), chlorophyll index (CI), leaf nitrogen concentration (LNC) and grain nitrogen concentration (GNC) of maize plants influenced by inoculation of associative diazotrophic bacteria and nitrogen fertilization.

\begin{tabular}{|c|c|c|c|c|c|c|c|c|c|c|}
\hline \multirow[t]{2}{*}{ Inoculation } & \multicolumn{2}{|l|}{$\begin{array}{l}\text { PH } \\
(\mathrm{cm})\end{array}$} & \multicolumn{2}{|l|}{$\begin{array}{l}\text { HSI } \\
(\mathrm{cm})\end{array}$} & \multicolumn{2}{|l|}{$\begin{array}{l}\text { SD } \\
(\mathrm{mm})\end{array}$} & \multicolumn{2}{|l|}{$\mathrm{CI}$} & \multirow{2}{*}{$\begin{array}{l}\mathrm{LNC} \\
\left(\mathrm{g} \cdot \mathrm{kg}^{-1}\right)\end{array}$} & \multirow{2}{*}{$\begin{array}{l}\mathrm{GNC} \\
\left(\mathrm{g} \cdot \mathrm{kg}^{-1}\right)\end{array}$} \\
\hline & VT & R3 & VT & R3 & VT & R3 & VT & R3 & & \\
\hline Control & $180.63^{\mathrm{ns}}$ & $184.80^{\mathrm{ns}}$ & $87.23 \mathrm{a}$ & $94.20 \mathrm{a}$ & $23.47^{\mathrm{ns}}$ & $21.06^{\mathrm{ns}}$ & $53.83^{\mathrm{ns}}$ & $55.25^{\mathrm{ns}}$ & $8.61^{\mathrm{ns}}$ & $5.23 \mathrm{a}$ \\
\hline MTAz8 & 175.32 & 180.80 & $83.15 \mathrm{ab}$ & $90.00 \mathrm{ab}$ & 22.68 & 19.87 & 53.53 & 54.43 & 27.12 & $13.86 \mathrm{~b}$ \\
\hline MTh2 & 172.38 & 178.43 & $78.73 \mathrm{~b}$ & $87.93 \mathrm{~b}$ & 23.69 & 20.71 & 53.28 & 54.18 & 28.18 & $14.22 \mathrm{ab}$ \\
\hline $\mathrm{AbV} 5+\mathrm{AbV} 6$ & 178.32 & 180.87 & $82.80 \mathrm{ab}$ & $90.33 \mathrm{ab}$ & 23.70 & 19.97 & 52.71 & 52.76 & 28.91 & $13.94 \mathrm{ab}$ \\
\hline \multicolumn{11}{|c|}{ Nitrogen fertilization $\left(\mathrm{kg} \cdot \mathrm{ha}^{-1}\right)$} \\
\hline 0 & $166.56 \mathrm{~b}$ & $174.85 \mathrm{~b}$ & $80.41 \mathrm{~b}$ & $87.94 \mathrm{~b}$ & $23.19^{\mathrm{ns}}$ & $19.93^{\mathrm{ns}}$ & $51.07 \mathrm{c}$ & $51.28 \mathrm{~b}$ & $26.85 \mathrm{~b}$ & $13.75 \mathrm{~b}$ \\
\hline 55 & $180.43 \mathrm{a}$ & $183.94 \mathrm{a}$ & $85.13 \mathrm{a}$ & $92.61 \mathrm{a}$ & 22.85 & 20.14 & $53.44 \mathrm{~b}$ & $54.42 \mathrm{a}$ & $28.22 \mathrm{ab}$ & $13.91 \mathrm{~b}$ \\
\hline 110 & $183.00 \mathrm{a}$ & $185.01 \mathrm{a}$ & $83.40 \mathrm{ab}$ & $91.30 \mathrm{ab}$ & 24.11 & 21.14 & $55.51 \mathrm{a}$ & $56.67 \mathrm{a}$ & $29.54 \mathrm{a}$ & $15.28 \mathrm{a}$ \\
\hline
\end{tabular}

Values followed by the same letter, in column, are not significantly different at $\mathrm{p}<0.05$ according to LSD test. ${ }^{\text {ns }}$ non-significant at $\mathrm{p}<0.05$ by $\mathrm{F}$ te 
Table 4. Aboveground dry matter of maize $\left(\mathrm{kg} \cdot \mathrm{ha}^{-1}\right)$ influenced by inoculation of associative diazotrophic bacteria and nitrogen fertilization.

\begin{tabular}{lccc}
\hline \multirow{2}{*}{ Inoculation } & \multicolumn{3}{c}{ Nitrogen Fertilization $\left(\mathrm{kg} \cdot \mathrm{ha}^{-1}\right)$} \\
\cline { 2 - 4 } & 0 & 55 & 110 \\
\hline Control & $4240.74 \mathrm{aB}$ & $4794.77 \mathrm{abAB}$ & $5627.73 \mathrm{abA}$ \\
MTAz8 & $4813.29 \mathrm{aA}$ & $4563.94 \mathrm{bA}$ & $5006.76 \mathrm{abA}$ \\
MTh2 & $4518.57 \mathrm{aB}$ & $5809.31 \mathrm{aA}$ & $4609.17 \mathrm{bB}$ \\
AbV5 + AbV6 & $4671.30 \mathrm{aB}$ & $4773.94 \mathrm{abAB}$ & $5875.79 \mathrm{aA}$ \\
\hline
\end{tabular}

Values followed by the same capital letter in line, and a small letter in column are not significantly different at $\mathrm{p}<0.05$ according to LSD test. ${ }^{\mathrm{n} s}$ non-significant at $\mathrm{p}<0.05$ by $\mathrm{F}$ test.

Table 5. Grain yield of maize $\left(\mathrm{kg} \cdot \mathrm{ha}^{-1}\right)$ influenced by inoculation of associative diazotrophic bacteria and nitrogen fertilization.

\begin{tabular}{llccc}
\hline \multirow{2}{*}{ Inoculation } & \multicolumn{3}{c}{ Nitrogen Fertilization $\left(\mathrm{kg} \cdot \mathrm{ha}^{-1}\right)$} & \multirow{2}{*}{ Mean } \\
\cline { 2 - 4 } & 0 & 55 & 110 & \\
\hline Control & $6335.95^{\mathrm{ns}}$ & $7378.75^{\mathrm{ns}}$ & $8258.95^{\mathrm{ns}}$ & $7324.54^{\mathrm{ns}}$ \\
MTAz8 & 7285.41 & 7151.17 & 7695.19 & 7377.26 \\
MTh2 & 6926.56 & 8092.53 & 6904.07 & 7307.72 \\
AbV5 + AbV6 & 6537.31 & 7711.73 & 7817.81 & 7355.62 \\
\hline Mean & $6771.31 \mathrm{~B}$ & $7583.54 \mathrm{~A}$ & $7669.01 \mathrm{~A}$ & --- \\
\hline
\end{tabular}

Values followed by the same letter, in column, are not significantly different at $\mathrm{p}<0.05$ according to LSD test. ${ }^{n} \overline{\text { non-significant at } \mathrm{p}}<0.05$ by $\mathrm{F}$ test.

obtaining an increase of $1,200 \mathrm{~kg} \mathrm{ha}^{-1}$ in aboveground DM production. Lana et al. (2012) described similar results by assessing the inoculation with $A$. brasilense and $\mathrm{N}$ doses applied at topdressing. The authors observed significant interaction between the factors, where inoculation with $A$. brasilense allowed greater production of aboveground DM of plants regardless of $\mathrm{N}$ supply at topdressing, suggesting the possibility of partial replacement of $\mathrm{N}$ fertilization by inoculation. Another interesting result was that Mth2 associated with $55 \mathrm{~kg} \mathrm{ha}^{-1}$ of $\mathrm{N}$ fertilizer produced similar amounts of aboveground dry mass to the treatment inoculated with commercial inoculant associated with 110 $\mathrm{kg} \mathrm{ha}^{-1}$, that is, a $50 \%$ saving of $\mathrm{N}$ fertilizer, which may be related to the greater adaptive capacity of the edaphoclimatic conditions of the region where the maize was grown (Table 4). The low responsiveness of the commercial inoculants used in this study in relation to isolates may be attributed to adaptation of strains to local conditions. Cavallet et al. (2000) highlight that selecting strains adapted to local conditions and to crops and cultivars used in each region is an aspect that must be considered in the recommendation of a commercial product based on diazotrophic bacteria. It is necessary to evaluate and select the strain based on their adaptability to climate and crop management. On the other hand, the bacteria evaluated in this study were isolated from maize plants grown under local climate conditions, precipitation and soil, similar to those obtained in the experimental area where the study was conducted. These factors may have been essential for a better association between diazotrophic bacteria and plants.

The doses of $\mathrm{N}$ fertilizer significantly increased grain yield by 10.71 and $11.71 \%$, when $55 \mathrm{~kg} \mathrm{ha}^{-1}$ and $110 \mathrm{~kg} \mathrm{ha}^{-}$ ${ }_{1}$ of $\mathrm{N}$ was supply, respectively (Table 5). There was no significant effect of inoculation on grain yield, with an average of $7,341.29 \mathrm{~kg} \mathrm{ha}^{-1}$. Although grain yield was not influenced by inoculation, the commercial inoculant and isolates MTh2 and MTAz8 showed higher yield in the absence of $\mathrm{N}$ fertilization with increases of 201.36, 590.61 and $949.46 \mathrm{~kg} \mathrm{ha}^{-1}$, which represents a gain of 3,9 and 15 bags per hectare, suggesting the benefit of inoculation to the maize crop (Table 5). Studies carried out by Dartora et al. (2013) also showed increases of $922 \mathrm{~kg} \mathrm{ha}^{-1}$ with the combined inoculation of strains Ab-V5 (Azospirillum brasilense) and SmR1 (Herbaspirillum $s p$.), representing a gain of 15 bags per ha when compared to the control without inoculation, although these results were not significant in the statistical test. The association of inoculation of MTh2 and $55 \mathrm{~kg} \mathrm{ha}^{-1}$ indicates an increase in production by $713.78 \mathrm{~kg} \mathrm{ha}^{-1}$ compared with the treatment without fertilization. The commercial inoculant provided gains of $332.98 \mathrm{~kg} \mathrm{ha}^{-1}$ representing an increase of 8.8 and $4.3 \%$ in grain yield, respectively (Table 5). However, when $110 \mathrm{~kg} \mathrm{ha}^{-1}$ of $\mathrm{N}$ were supplied, all inoculated treatments had lower production than those without inoculation, which may have been a reflection of an inhibition caused by $\mathrm{N}$ on the bacterial colonization of plants (Roesch et al., 2006). The increase in $\mathrm{N}$ concentration in the soil has an inhibitory effect on biological $\mathrm{N}$ fixation, because this nutrient alters the physiological state of the plant and, therefore, its association to the diazotrophic bacteria (Reis et al., 2000). Hungria (2011), studying with the maize culture, noted that in treatments with $100 \%$ of $\mathrm{N}$ in the form of urea, the effect of inoculation with Azospirillum was generally nulled. Experiments with $\mathrm{N}$ fertilization provide higher grain yield when compared to use of diazotrophic bacteria; however, this fact does not reduce the potential use of diazotrophic bacteria (Hungria et al., 2010). In this sense, the use of microorganisms in agriculture can contribute to reducing the use of $\mathrm{N}$ fertilizers as well as improving efficiency of nutrient absorption, cooperating for the development of production systems based on agricultural sustainable concepts.

\section{Materials and methods}

\section{Localization, plant material and soil characteristics}

The experiment was conducted in 2013/14 crop in the municipality of Campo Verde, Mato Grosso State, Brazil (15³3'37.4" S; 55॰10'47.7" $\mathrm{W}$ and altitude $736 \mathrm{~m})$. The climate is classified as Aw according Köppen climate classification system. Data on monthly precipitation and average temperatures during the experiment are presented in Fig. 1.

The soil was classified as Oxisol, with sandy-loam soil texture, whose chemical characteristics of layer $0-0.2 \mathrm{~m}$ are described in Table 1.

\section{Treatments}

The treatments were composed of the combination of two factors, inoculation and doses of $\mathrm{N}$ fertilizer. The first factor referred to seed inoculation with diazotrophic bacteria: treatment control, commercial inoculant (strains 
Ab-V5 and Ab-V6 Azospirillum brasilense), two isolates of associative diazotrophic bacteria (MTAz8 - similar to Azospirillum sp. and MTh2 - Bacillus sp.). The second factor comprised three doses of $\mathrm{N}$ fertilizer: 0,55 and 110 $\mathrm{kg} \mathrm{ha} \mathrm{a}^{-1}$ of $\mathrm{N}$, applied in the form of urea. The control treatment was not inoculated. In the treatments with $\mathrm{N}$ fertilizer, the $\mathrm{N}$ fertilization was performed for the treatments $\left(0,55\right.$ and $110 \mathrm{~kg} \cdot \mathrm{ha}^{-1}$ of $\left.\mathrm{N}\right)$ using urea $(46 \% \mathrm{~N})$ in two surface applications at 14 and 34 days after sowing (DAS), which corresponded to stages 3-4 and 7-8 of fully expanded leaves.

The strains of diazotrophic bacteria were isolated from the rhizosphere soil of maize plants grown on agricultural soil, following the methods of Döbereiner et al. (1995). The preparation of inoculants from isolates was carried out in the laboratory. Pure colonies of bacteria were grown in DYGS liquid medium to $100 \mathrm{rpm}$ at a concentration of $1 \mathrm{x}$ $10^{9} \mathrm{CFU} \mathrm{mL} \mathrm{m}^{-1}$. Later, $15 \mathrm{~mL}$ of bacterial grown was added to every $35 \mathrm{~g}$ of dry and sterile peat. The mixture was homogenized and kept in an incubator at $30^{\circ} \mathrm{C}$ for $24 \mathrm{~h}$ (Guimarães et al., 2007).

Inoculation of seeds was performed prior to sowing. To improve adhesion of the seed inoculant, it was used a sugar solution at $10 \%(\mathrm{~m} / \mathrm{v})$ and later $250 \mathrm{~g}$ of peat inoculant for each $50 \mathrm{~kg}$ of seeds was added. The commercial inoculant (Composed by strains AbV5 and AbV6 of A. brasilense) was used in the liquid form, according to manufacturer recommendation, at the rate of $100 \mathrm{~mL}$ for each $50 \mathrm{~kg}$ of seeds.

\section{Experimental design and conduction}

The experiment was arranged in a randomized complete block design, in bifactorial scheme $4 \times 3$, with 12 treatments and four replicates. The first factor referred to seed inoculation with diazotrophic bacteria (control, commercial inoculant, MTAz8 and MTh2) and the second factor comprised three doses of $\mathrm{N}$ fertilizer $\left(0,55\right.$ and $110 \mathrm{~kg} \cdot \mathrm{ha}^{-1}$ of $\mathrm{N}$ ).

Sowing was carried out manually, using the triple hybrid 2B688PW. Each experimental unit consisted of four lines 4 $\mathrm{m}$ long, $0.9 \mathrm{~m}$ spacing with five plants per meter, totaling $14.4 \mathrm{~m}^{2}$. As useful area, two centerlines were used discarding $0.5 \mathrm{~m}$ from each end, totaling $5.4 \mathrm{~m}^{2}$. Following the recommendations of Sousa and Lobato (2004), fertilization was performed at the time of sowing with 80 $\mathrm{kg} \mathrm{ha}{ }^{-1}$ of $\mathrm{P}_{2} \mathrm{O}_{5}$ and $60 \mathrm{~kg} \mathrm{ha}$ of $\mathrm{K}_{2} \mathrm{O}$, using superphosphate and potassium chloride, respectively, as a source.

During the experiment, insecticides and fungicides were applied for plant disease control with the active ingredients, methomyl $\left(0.6 \mathrm{~L} \cdot \mathrm{ha}^{-1}\right)$ and imidacloprid + beta-cyfluthrin $\left(0.8 \mathrm{~L} \cdot \mathrm{ha}^{-1}\right)$ to control armyworm (Spodoptera frugiperda) and maize leafhopper (Dalbulus maidis). To control the brown eyespot (Cercospora zeae-maydis) and blotch (Exserohilum turcicum), the active ingredient azoxystrobin + cyproconazole $\left(0.3 \mathrm{~L} \cdot \mathrm{ha}^{-1}\right)$ was used.

\section{Traits measured}

The evaluations were carried out in two phases of plant growth: at 63 DAS (VT stage - issuing of male inflorescences) and 90 DAS (R3 stage - viscous grain) (Magalhães et al., 2002). The readings of plant height and spike insertion, stem diameter and chlorophyll index were performed in five plants per area, using a graduated ruler, a digital caliper and digital chlorophyll meter, respectively.

The chlorophyll index assessment was performed at 63 and 90 DAS, with the aid of the digital chlorophyll meter portable Falker, model ClorofiLOG CFL1030. The readings were always performed on the index leaf, positioned just below the spike insertion (Argenta et al., 2003). For the composition of the means, two readings were performed in different points of the leaf and in five plants per plot, totaling 10 measurements per plot. In the assessment at 63 DAS, three leaves of each plot were collected to evaluate foliar $\mathrm{N}$ concentration, according to the Kjeldahl method described by Silva (2009).

The harvesting was carried out manually at 125 DAS, collecting five demarcated plants in the area. The plants were placed in paper bags, identified and taken to a forcedair circulation oven at $65 \pm 2{ }^{\circ} \mathrm{C}$ until constant weight for subsequent weighing and determining the dry matter. The spikes were removed and threshed to determine productivity in $\mathrm{kg} \mathrm{ha}^{-1}$ after correction of grain moisture to $13 \%$.

The grains were dried in an air-forced circulation oven at $65 \pm 2{ }^{\circ} \mathrm{C}$, ground in a Wiley-type mill with $1 \mathrm{~mm}$ mesh and later, $\mathrm{N}$ concentration was determined according to the method of Kjeldahl and described by Silva (2009).

\section{Statistical analysis}

The evaluated characteristics were submitted to the analysis of normality of residuals with the Kolmogorov-Smirnov test and the analysis of variance of the F-test. When the factors were significant, the LSD test was applied for comparison between means. The analyses were carried out using the SISVAR statistical program v.5.3, at a significance level of $\alpha=0.05$ (Ferreira, 2011).

\section{Conclusion}

Select diazotrophic bacteria specifically adapted to local edaphoclimatic conditions is an important alternative to reduce production costs and environmental impacts caused by the addition of $\mathrm{N}$ in the soil. Our results show that inoculation the isolates MTAz8 and MTh2, in the absence or presence of $\mathrm{N}$ fertilizer promotes a substantial increase in aboveground dry matter production in relation to the commercial inoculant, confirming our hypothesis. In addition, our results suggest that inoculation promotes increases in grain yield, even without application of $\mathrm{N}$ fertilizer.

\section{Conflict of interests}

The authors have declared no conflict of interests.

\section{Acknowledgment}

The Support Foundation Soybean (FACS/MT) and Soybean Producers Association and Maize the State of Mato Grosso (APROSOJA/MT) for granting scholarship.

\section{References}

Argenta G, Silva PRF, Fosthofer EL, Strieder ML, Suhre E, Teichmann LL (2003) Nitrogen fertilization in maize by monitoring the plant $n$ level by a chlorophyll meter. Rev Bras Cienc Solo. 27(1):109-119.

Brandão EM (1992) Os componentes da comunidade microbiana do solo. In: Cardoso EJBN, Tsai SM, Neves MCP. Microbiologia do Solo. Soc Bras Cienc Solo.

Cantarella H, Duarte AP (2004) Manejo da fertilidade do solo para a cultura do milho. In: Galvão, JCC, Miranda GV. Tecnologia de produção de milho. Editora UFV. 
Cavallet LE, Pessoa ACS, Helmich JJ, Helmich PR, Ost CF (2000) Corn productivity in response to nitrogen application and seed inoculation with Azospirillum spp. Rev Bras Eng Agr Amb. 4(1):129-132.

Chapman SC, Barreto HJ (1997) Using a chlorophyll meter to estimate specific leaf nitrogen of tropical maize during vegetative growth. Agron J. 89(1):557-562.

CONAB - Companhia Nacional de Abastecimento (National Supply Company) Monitoring of Brazilian grain harvest: Safra 2013/2014. Brasília: CONAB, 2014. Available at: <http://www.conab.gov.br/OlalaCMS/uploads/arquivos/1 4_09_10_14_35_09_boletim_graos_setembro_2014.pdf> . Accessed on: September, 17, 2016

Conceição PC, Amado TJC, Mielniczuk J, Spagnollo E (2005) Soil organic matter and other attributes as indicators to evaluate soil quality in conservation systems. Rev Bras Cienc Solo. 29(5):777-788.

Dartora J, Guimarães VF, Marini D, Sander G (2013) Nitrogen fertilization associated to inoculation with Azospirillum brasilense and Herbaspirillum seropedicae in the maize. Rev Bras Eng Agr Amb. 17(10):1023-1029.

Döbereiner J, Baldani VLD, Baldani JI (1995) Como isolar e identificar bactérias diazotróficas de plantas nãoleguminosas. Embrapa-SPI/Embrapa-CNPAB.

Dotto AP, Lana MC, Steiner F, Frandoloso JF (2010) Maize yield in response to Herbaspirillum seropedicae inoculation under different nitrogen levels. Rev Bras Cienc Agrar. 5(3):376-382.

Duete RRC, Muraoka T, Silva EC, Trivelin PCO, Ambrosano EJ (2008) Nitrogen fertilization management and nitrogen $\left({ }^{15} \mathrm{~N}\right)$ utilization by corn crop in red latosol. Rev Bras Cienc Solo. 32(1):161-171.

Ferreira DF (2011) Sisvar: a computer statistical analysis system. Cienc Agrotec. 35(6):1039-1042.

Gomes RF, Silva AG, Assis RL, Pires FR (2007) Effect of doses and timing of nitrogen application on agronomical traits of no-till corn. Rev Bras Cienc Solo. 31(5):931-938.

Guimarães SL, Baldani JI, Baldani VLD, Jacob-Neto J (2007) Addition of molybdenum in peat innoculum with diazotrophic bacteria used in two rice cultivars. Pesqui Agropecu Bras. 42(3):393-398.

Hungria M (2011) Inoculation with Azospirillum brasilense: innovation at low cost. EMBRAPA Soy. Documents, 325, Londrina. Available at: <http://www.cnpso.embrapa.br/download/doc325.pdf> Accessed on: July, 15, 2014.

Hungria M, Campo RJ, Souza EM, Pedrosa FO (2010) Inoculation with selected strains of Azospirillum brasilense and A. lipoferum improves yields of maize and wheat in Brazil. Plant Soil. 331(1):413-425.
Kappes C, Arf O, Arf MV, Ferreira JP, Bem EAD, Portugal JRP, Vilela RG (2013) Seeds inoculation with diazotrophic bacteria and nitrogen application in sidedressing and leaf in maize. Semin-Cienc Agrar. 34(2):527-538.

Lana MC, Dartora J, Marini D, Hann JE (2012) Inoculation with Azospirillum, associated with nitrogen fertilization in maize. Rev Ceres. 59(3):399-405.

Magalhães PC, Durães FOM, Carneiro NP, Paiva E (2002) Fisiologia do milho. Embrapa CNPMS.

Malavolta E (2006) Manual de nutrição mineral de plantas. Editora Ceres.

Moreira FMS, Silva K, Nóbrega RSA, Carvalho F (2010) Diazotrophic associative bacteria: diversity, ecology and potential applications. Com Sci. 1(2):74-99.

Okumura RS, Takahashi HW, Santos D, Lobato A, Mariano DDC, Marques OJ, Silva M, Oliveira Neto C, Lima Junior J (2011) Influence of different nitrogen levels on growth and production parameters in maize plants. J Food Agric Environ. 9(3):510-514.

Piccini C, Di Bene C, Farina R, Pennelli B, Napoli R (2016) Assessing nitrogen use efficiency and nitrogen loss in a forage-based system using a modeling approach. Agronomy. 6(2):23.

Quadros PD, Roesch LFW, Silva PRF, Vieira VM, Roehrs DD, Camargo FAO (2014) Field agronomic performance of maize hybrids inoculated with Azospirillum. Rev Ceres. 61(2):209-218.

Reis VM, Baldani VLD, Baldani JI, Döbereiner J (2000) Biological nitrogen fixation in gramineae and palm trees. Crit Rev Plant Sci. 19(3):227-247.

Reis VM, Teixeira KRS (2005) Fixação biológica do nitrogênio - estado da arte. In: Aquino AM, Assis RL. Processos biológicos no sistema solo - planta: ferramentas para uma agricultura sustentável. EMBRAPA Technological information.

Roesch LFW, Olivares FL, Passaglia LPM, Selbach PA, Sá ELS, Camargo FAO (2006) Characterization of diazotrophic bacteria associated with maize: effect of plant genotype, ontogeny and nitrogen-supply. World J Microb Biot. 22(9):967-974.

Santi C, Bogusz D, Franche C (2013) Biological nitrogen fixation in non-legume plants. Ann Bot-London. 111(5):1-25

Silva FC (2009) Manual de análises químicas de solos, plantas e fertilizantes. Embrapa Technological information.

Sousa DMG, Lobato E (2004) Cerrado: correção do solo e adubação. Embrapa Cerrados.

Souza EFC, Soratto RP (2006) Effect of sidedressing nitrogen sources and doses on out-of season corn in notillage system. Rev Bras Milho Sorgo. 5(3):395-405. 